

\section{DISCLAIMER}

This report was prepared as an account of work sponsored by an agency of the United States Government. Neither the United States Government nor any agency Thereof, nor any of their employees, makes any warranty, express or implied, or assumes any legal liability or responsibility for the accuracy, completeness, or usefulness of any information, apparatus, product, or process disclosed, or represents that its use would not infringe privately owned rights. Reference herein to any specific commercial product, process, or service by trade name, trademark, manufacturer, or otherwise does not necessarily constitute or imply its endorsement, recommendation, or favoring by the United States Government or any agency thereof. The views and opinions of authors expressed herein do not necessarily state or reflect those of the United States Government or any agency thereof. 


\section{DISCLAIMER}

Portions of this document may be illegible in electronic image products. Images are produced from the best available original document. 
Reference to a company or product name does not imply approval or recommendation of the product by Union Carbide Corporation or the U.S. Energy Research and Development Administration to the exclusion of others that may meet specifications.

\section{Printed in the United States of America. Available from} National Technical Information Service

U.S. Department of Commerce 5285 Port Royal Road, Springfield, Virginia 22161

Price: Printed Copy $\$ 4.00$; Microfiche $\$ 2.25$

This report was prepared as an account of work sponsored by the United States Government. Neither the United States nor the Energy Research and Development Administration, nor any of their employees, nor any of their contractors, subcontractors, or their employees, makes any warranty, express or implied, or assumes any legal liability or responsibility for the accuracy, completeness or usefulness of any information, apparatus, product or process disclosed, or represents that its use would not infringe privately owned rights. 
Date of Issue: September 29, 1975

Report Number: Y-1995

Distribution Category: UC-25

\title{
CHARACTERIZATION OF URANIUM-1 AND 2 WEIGHT PERCENT ZIRCONIUM ALLOYS
}

\author{
V.C. Hemperly \\ Metallurgical Development Department \\ Y-12 Development Division
}

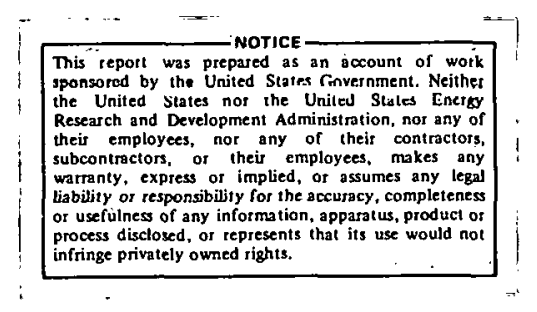

Oak Ridge Y-12 Plant

P. O. Box Y, Oak Ridge, Tennessee 37830

Prepared for the US Energy Research and Develnnminil Aidritinistration

Under US Government Contract W-7405-eng-26 


\begin{abstract}
A preparation method for wrought uranium-1 and 2 wt \% zirconium alloys has been developed. Tensile tests of the $2 \mathrm{wt} \%$ zirconium alloy demonstrate that it can be solution treated, water quenched, and age hardened to obtain high strength with good ductility; hardening response of the $1 \mathrm{wt} \%$ zirconium is much smaller. A metallographic study shows lliat the alluys on luwer-level aglng respond in a manner somewhat similar to the uranium-titanium alloys at comparable atomic percentage compositions.
\end{abstract}




\section{CONTENTS}

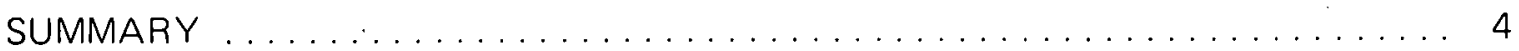

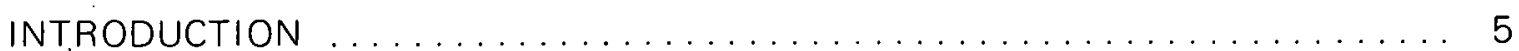

CHARACTERIZATION OF TWO URANIUM-ZIRCONIUM ALLOYS . . . . . . . 6

Alloy Preparation . . . . . . . . . . . . . . . . . . . . . . . . 6

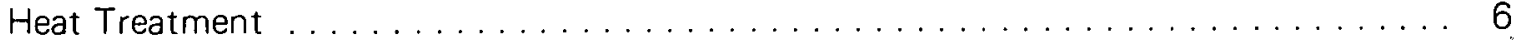

Mechanical Properties.................................. 6

Metallography ................................. 6

Conclusions ................................ 7

REFERENCES ............................... 13 


\section{SUMMARY}

Wrought uranium-1 and 2 wt \% zirconium alloys were prepared by vacuum-induction melting, casting, homogenizing, and rolling in the high-alpha region. The alloys did respond to solution treatment, water quenching, and age hardening like other alloys of low-level, gamma-miscible elements in uranium. The $1 \mathrm{wt} \%$ zirconium alloy attained a $1150-\mathrm{MPa}$ tensile strength, a $450-\mathrm{MPa}$ yield strength $(0.2 \%)$, a $30 \%$ alongation, and a $32 \%$ reduction in area; the 2 wt \% zirconium alloy attained a 1580-MPa tensile strength, a 1000-MPa yield strength, an $18 \%$ elongation, and a $36 \%$ reduction in area. In both alloys, most of the hardening occurred in the quench, and both overaged with a $400^{\circ} \mathrm{C}, 24$-hour treatment. $A$ metallographic study showed that both alloys responded to aging in a manner somewhat similar to the uranium-titanium alloys at comparable atomic-percentage compositions. 


\section{INTRODUCTION}

The mechanical properties of uranium can be markedly improved by alloying the metal, followed by a proper heat treatment. In general, low-level alloys of the gamma-miscible elements in uranium can be solution treated, water quenched, and then age hardened to obtain relatively high strengths with good ductility. This particular study was made at the Oak Ridge $Y-12$ Plant (a) to examine this generality with respect to the uranium-zirconium alloy system.

The literature is concerned mostly with the uranium-zirconium system at high levels of zirconium in uranium or with ternary alloys containing zirconium, both for nuclear reactor service. Chiswik, et al (1), did evaluate uranium-2 and 3 wt \% zirconium alloys, but no attempt was made to obtain a high strength. Johnson (2) in unpublished work concerning cast-metal alloys demonstrated that uranium- $0.5 \mathrm{wt} \%$ zirconium alloys did not respond to age hardening after solution treatment, water quenching, and aging at $4000 \mathrm{C}$, while the alloys at 1.0 and $1.4 \mathrm{wt} \%$ zirconium could be age hardened. The study levels of 1 and $2 \mathrm{wt}$ $\%$ zirconium in this report were selected on the basis of that work. However, wrought, rather than cast , metal is characterized here. Uranium- 0.75 to $1.1 \mathrm{wt} \%$ zirconium alloys have been examined for weld strength, but without any attempts to obtain high strength levels by heat treating. (3)

Caution: Alloys of uranium and zirconium may produce explosions on pickling in nitric acid. Although the problem is mostly with the higher zirconium alloys, explosions have been reported at the one percent zirconium level. Hydrofluoric acid addition to the pickling bath eliminates the problem.

(a) Operated by the Union Carbide Corporation's Nuclear Division for the US Energy Research and Development Administration. 


\section{CHARACTERIZATION OF TWO URANIUM-ZIRCONIUM ALLOYS}

\section{ALLOY PREPARATION}

Both alloys were prepared by comelting a uranium-10 wt \% zirconium master alloy and Derby-grade uranium in a vacuum-induction furnace using a graphite crucible that was plasma-arc sprayed with zirconia to minimize the metal/crucible reaction. The $1 \mathrm{wt} \%$ alloy was charged to $1.1 \mathrm{wt} \%$ zirconium and the $2 \mathrm{wt} \%$ alloy was charged to $2.2 \mathrm{wt} \%$ zirconium. Small ingots of each $(40 \times 125 \times 180 \mathrm{~mm})$ were poured at $1450^{\circ} \mathrm{C}$ in graphite molds washed with Zirconite A. After vacuum homogenization at $1000^{\circ} \mathrm{C}$ for four hours, both ingots were rolled to $13-\mathrm{mm}$ plates from an argon-atmosphere furnace set at $575^{\circ} \mathrm{C}$.

Chemical analyses of the two ingots are reported in Table 1. Hydrogen, which is detrimental to the mechanical properties of uranium and uranium alloys, is readily removed by vacuum treating at elevated temperatures. For this reason, the hydrogen determinations were made after the solution treatment at $800^{\circ} \mathrm{C}$ in vacuum. Zirconium in the $1 \mathrm{wt} \%$ alloy was just slightly lower than anticipated. Some of the carbon was removed by the flotation of zirconium carbide particles in the melt, so the carbon levels were also lower in the ingots than in the charge metal.

Table 1

CHEMICAL ANALYSIS OF URANIUM-1 AND 2 WT \% ZIFCONIUM ALLOYS

\begin{tabular}{ccc}
\hline $\begin{array}{c}\text { Zirconium } \\
\text { (wt \%) }\end{array}$ & $\begin{array}{c}\text { Carbon } \\
\text { (ppm) }\end{array}$ & $\begin{array}{c}\text { Hydrogen } \\
\text { (ppm) }\end{array}$ \\
\hline 0.86 & 23 & 0.15 \\
1.98 & 24 & 0.17 \\
\hline
\end{tabular}

\section{HEAT TREATMENT}

Test blanks, $13 \times 13 \times 125 \mathrm{~mm}$, were cut from the plates, solution treated in vacuum at $800 \cup \mathrm{C}$ tor one hour, and then water quenched. The various aging treatments were also performed in a vacuum-atmosphere furnace.

\section{MECHANICAL PROPERTIES}

Plots of the tensile-test results after selected heat treatments are given in Figure 1 for the 1 wt \% zirconium alloy and in Figure 2 for the 2 wt \% zirconium alloy. The 1 wt \% zirconium alloy hardened some small amount and was overaged when treated at $400^{\circ} \mathrm{C}$ for 24 hours. On the other hand, the '2 wt \% zirconium alloy did age harden signiticantly, and it also overaged after 24 hours at $400 \mathrm{C} \mathrm{C}$. In both alloys, the major portion of the age-hardenıng response occurred during the quench from the solution-treating temperature rather than on reheating. As with other age-hardening alloys, the response to aging would be different at other quenching-blank thicknesses.

\section{METALLOGRAPHY}

Figures 3 and 4 are polarized light photomicrographs of the two alloys in the gamma-quenched condition. The matrix of the $1 \mathrm{wt} \%$ zirconium alloy is alpha uranium; the matrix of the $2 \mathrm{wt} \%$ zirconium alloy is lamellar martensite. X-ray diffraction analyses demonstrated that the 2 wt \% alloy, as gamma quenched, 'was alpha-prime uranium. The alpha prime is an orthorhombic transition phase with a contraction of the $b$ parameter as 
compared with the a and c parameters. Comparable gamma-quenched structures are obtained with uranium-titanium alloys at comparable atomic-percent compositions 10.48 and 1.0 wt $\%$ Ti). (4)

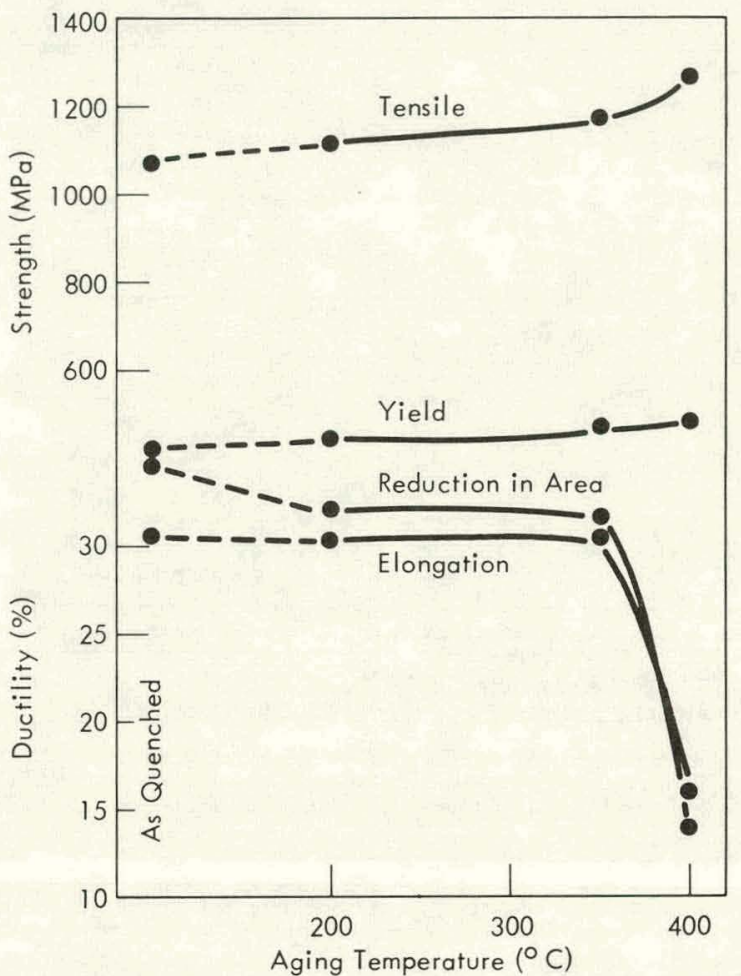

Figure 1. TENSILE TESTS OF THE URANIUM-1 WT \% ZIRCONIUM ALLOY AFTER SELECTED HEAT TREATEMENTS. (Average of 2 Tests)

here. Metallography of the 1 wt \% titanium alloy would show nucleation and growth of alpha uranium at the grain boundaries on overaging.

Density determinations and elastic moduli (sonic) of age-hardened materials are reported in Table 2. The moduli are comparable to those obtained by Johnson for 1 and 1.4 wt \% zirconium alloys of cast metal.

\section{Conclusions}

The uranium-1 and 2 weight percent zirconium alloys do respond to solution treatment, quenching, and aging, as with other low-level, gamma-miscible elements in
As indicated in Figures 5 and 6 , aging the uranium-zirconium alloys at $300^{\circ} \mathrm{C}$ for 24 hours did not change the metallographic structures. Such behavior is also normal for the comparable age-hardened uranium-titanium alloys.

Figures 7 and 8 are polarized light photomicrographs of the alloys aged at $400^{\circ} \mathrm{C}$ for 24 hours. Overaging, indicated by precipitation of the delta phase, is evident; but this phenomenon is more readily discerned under bright-field illumination in Figures 9 and 10 . The uranium-titanium analogy is not applicable

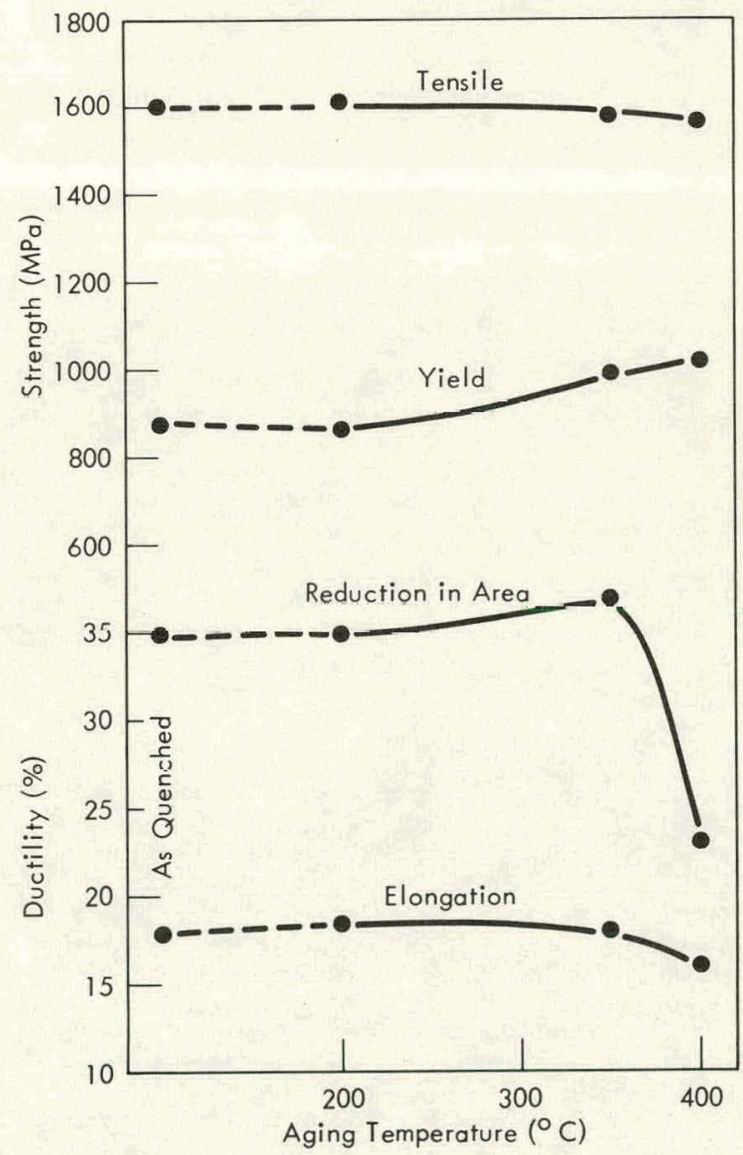

Figure 2. TENSILE TESTS OF THE URANIUM-2 WT \% ZIIRCONIUM ALLOY AFTFR SFIFCTFD HEAT TREATMENTS. (Average of 2 Tests) 


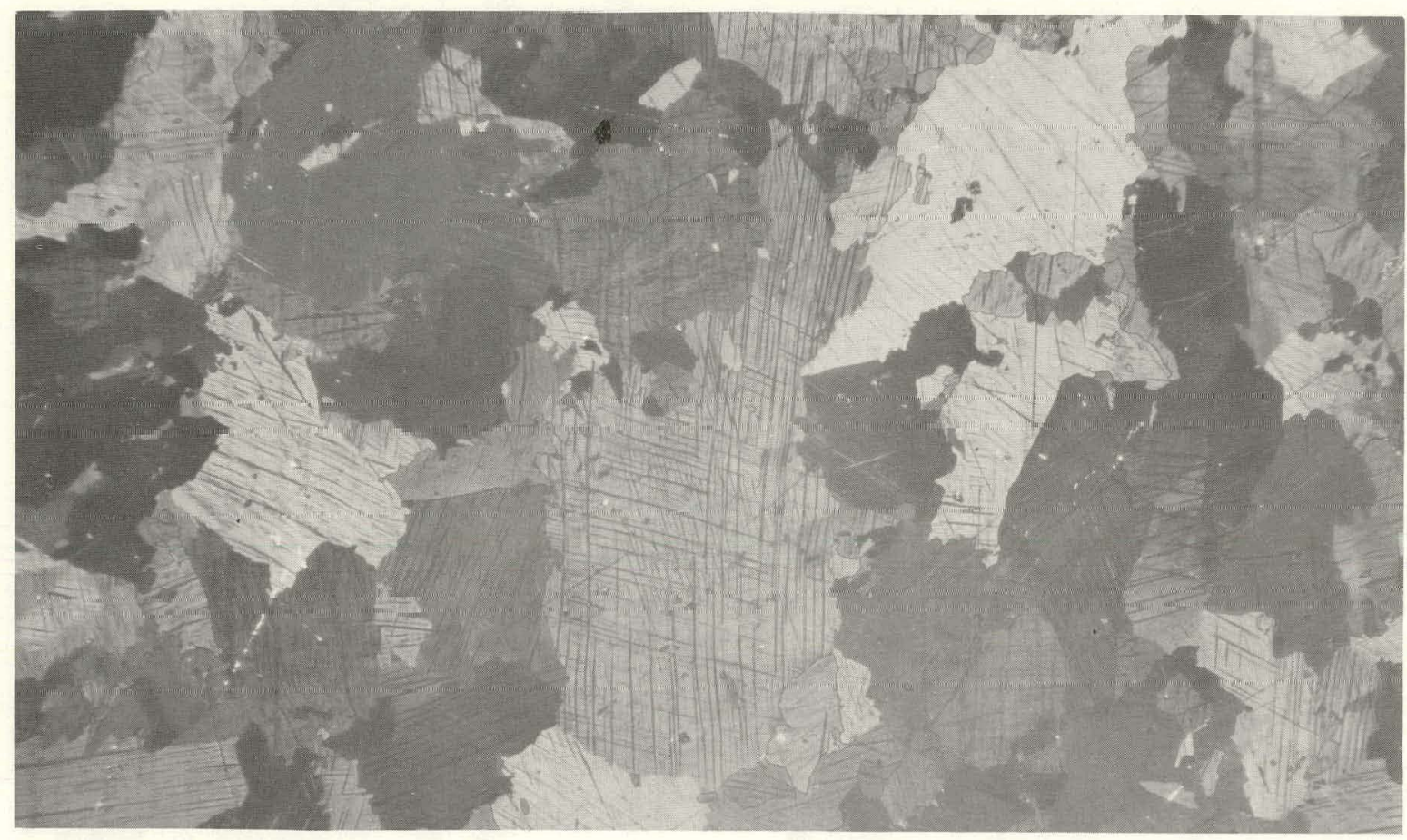

L48-A

Figure 3. PHOTOMICROGRAPH OF URANIUM-1 WT \% ZIRCONIUM ALLOY, AS QUENCHED (Polarized Light: 100X)

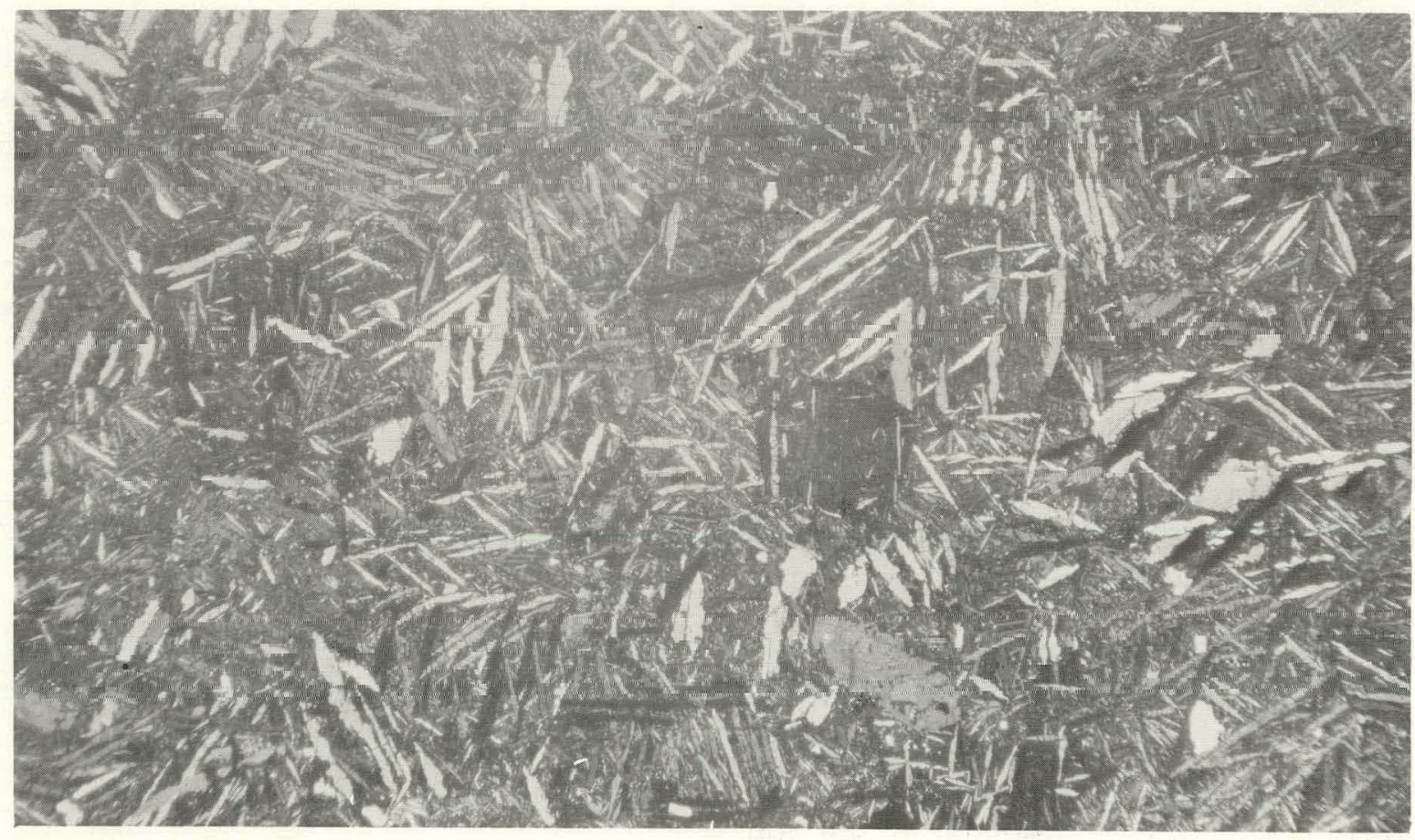

L60-A

Figure 4. PHOTOMICROGRAPH OF URANIUM-2 WT \% ZIRCONIUM ALLOY, AS QUENCHED. (Polarized Light; 100X) 


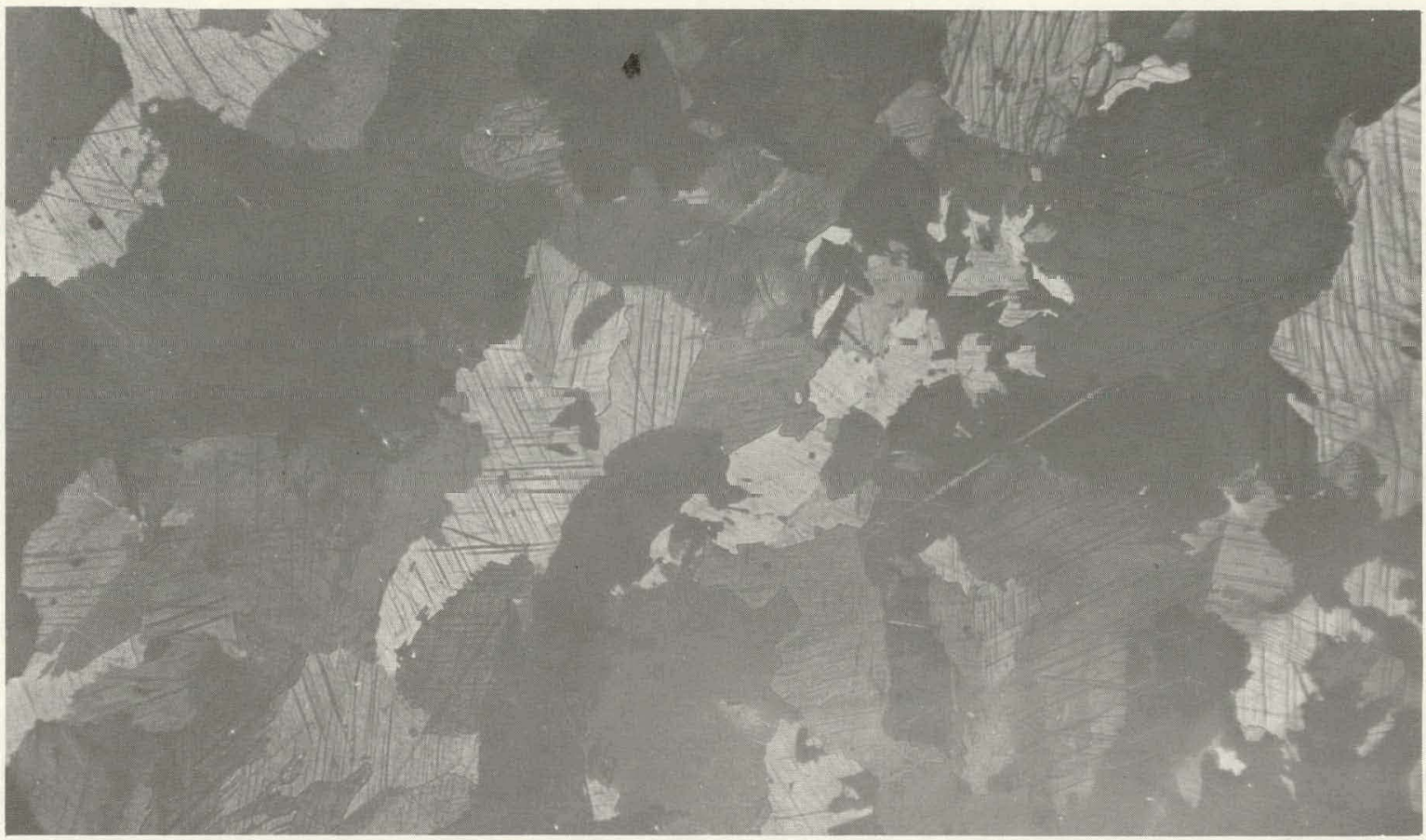

L78-1

Figure 5. PHOTOMICROGRAPH OF URANIUM-1 WT \% ZIRCONIUM ALLOY THAT WAS GAMMA QUENCHED AND AGE HARDENED AT $300^{\circ}$ C FOR 24 HOURS. (Polarized Light; 100X)

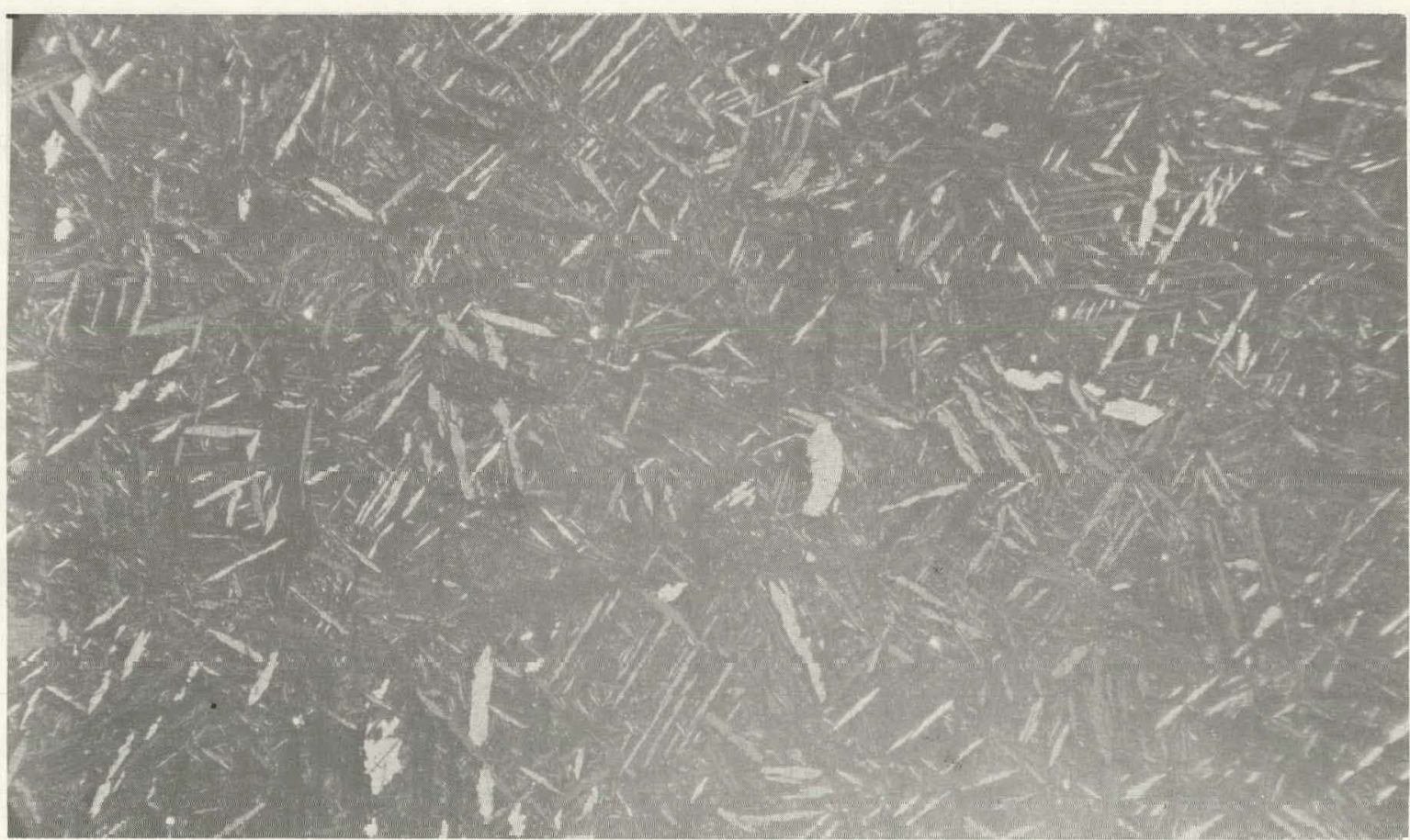

L78-2

Figure 6. PHOTOMICROGRAPH OF URANIUM-2 WT \% ZIRCONIUM ALLOY THAT WAS GAMMA QUENCHED AND AGE HARDENED AT $300^{\circ}$ C FOR 24 HOURS. (Polarized Light; 100X) 


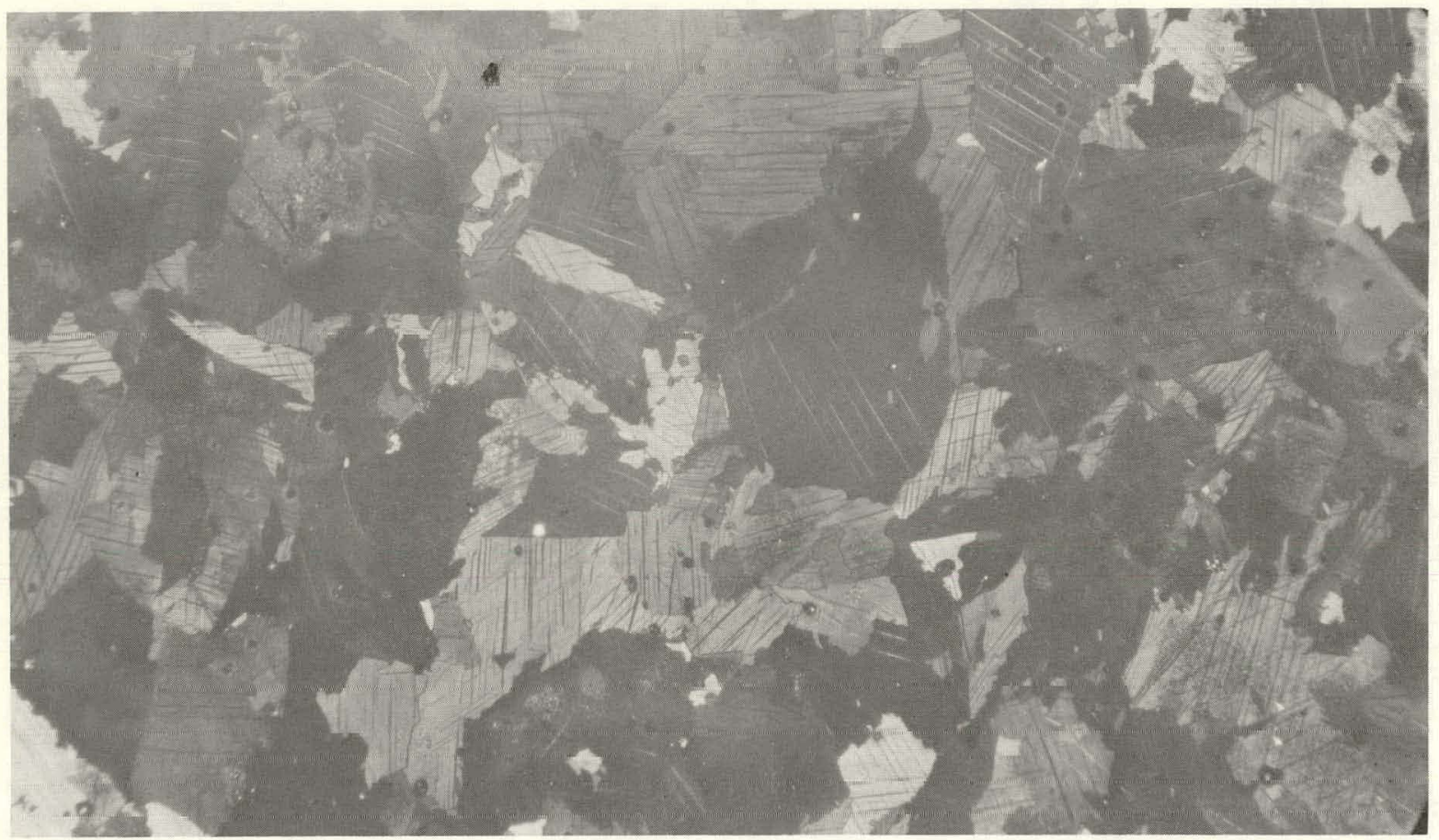

L125-1

Figure 7. PHOTOMICROGRAPH OF URANIUM-1 WT \% ZIRCONIUM ALLOY THAT WAS GAMMA QUENCHED AND OVERAGED AT $400^{\circ}$ C FOR 24 HOURS. (Polarized Light; 100X)

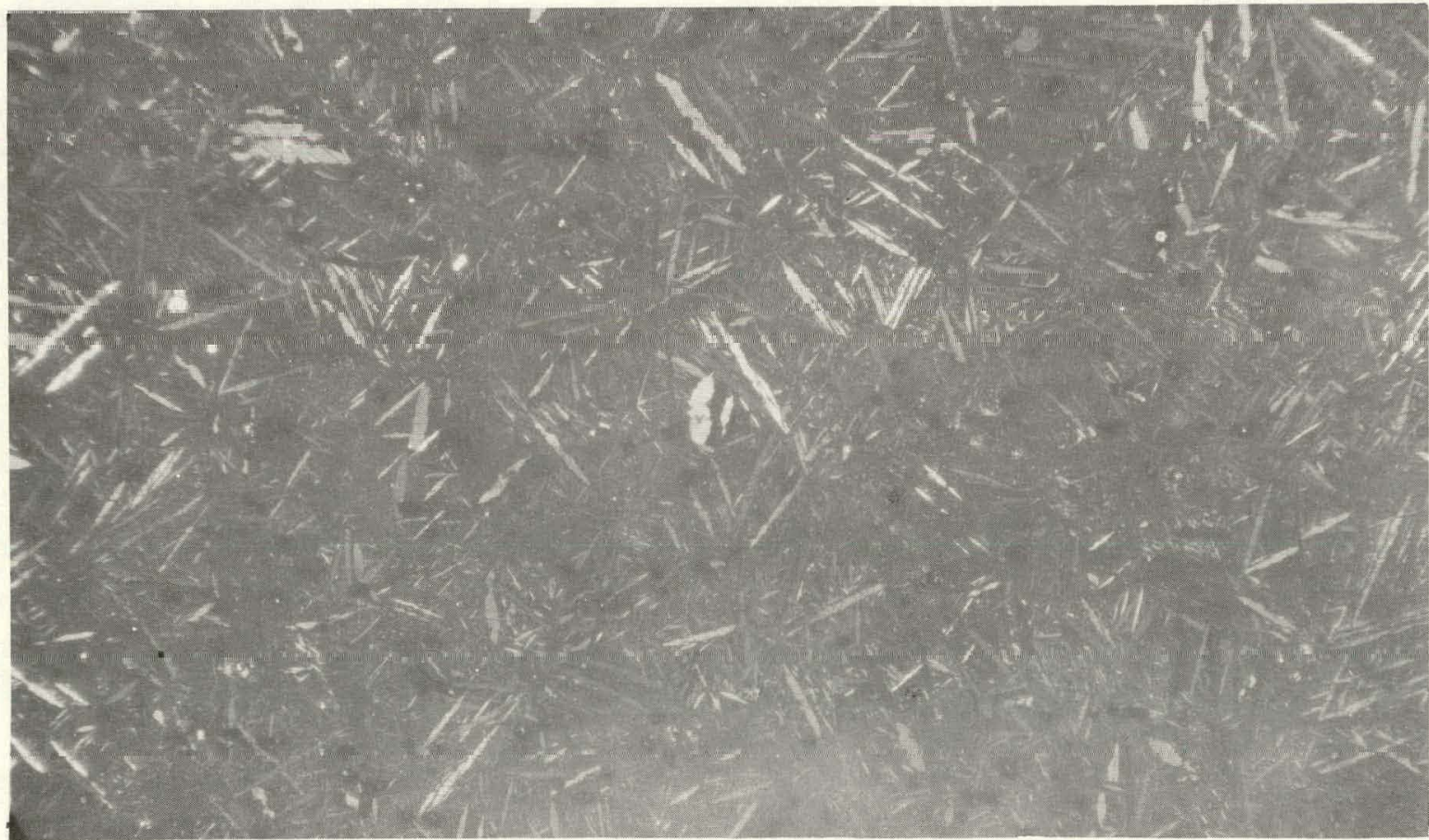

L125-2

Figure 8. PHOTOMICROGRAPH OF URANIUM-2 WT \% ZIRCONIUM ALLOY THAT WAS GAMMA QUENCHED AND OVERAGED AT $400^{\circ} \mathrm{C}$ FOR 24 HOURS. (Polarized Light; 100X) 


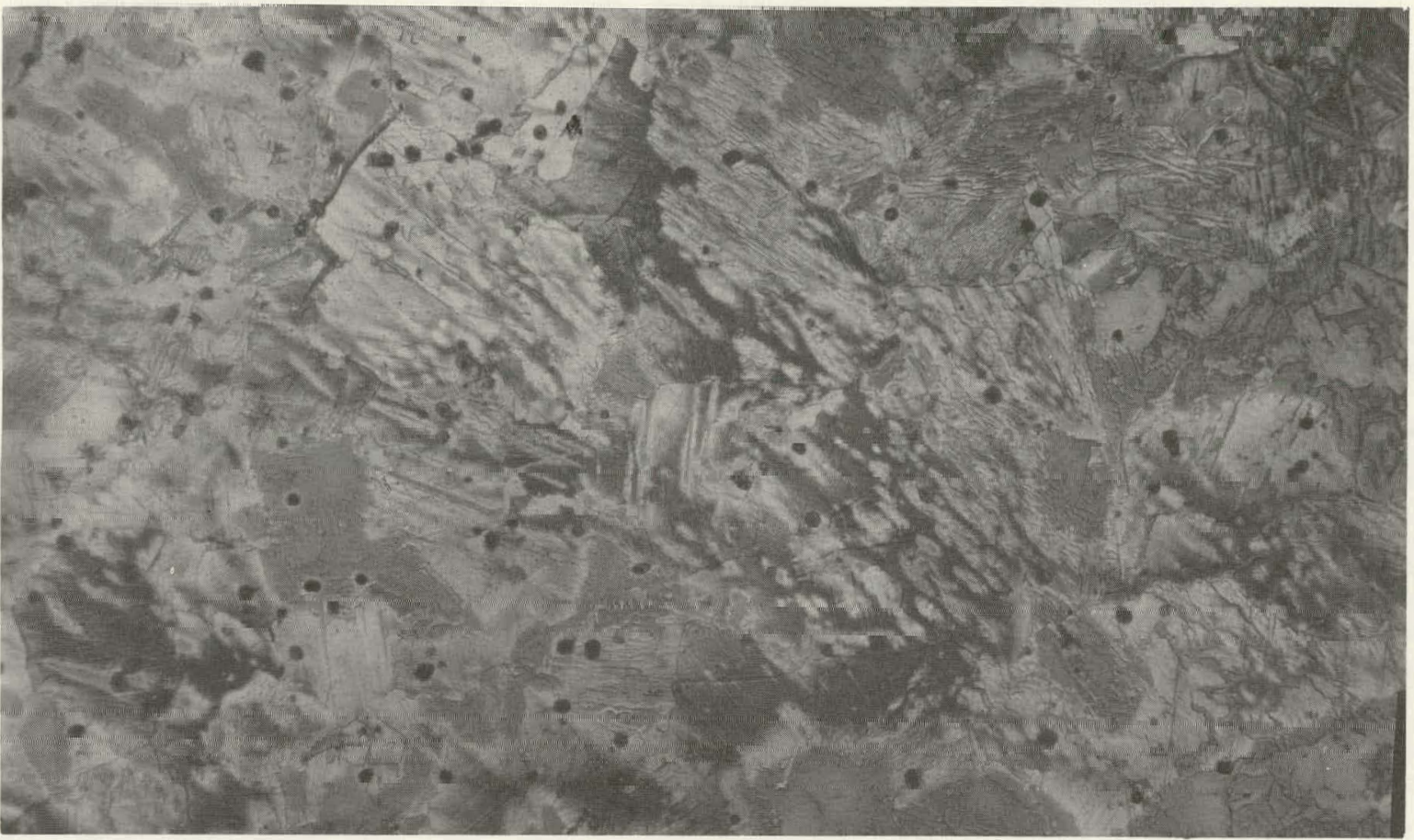

125-1A

Figure 9. PHOTOMICROGRAPH OF URANIUM-1 WT \% ZIRCONIUM ALLOY THAT WAS GAMMA QUENCHED AND OVERAGED AT $400^{\circ}$ C FOR 24 HOURS. (Bright Field Illumination; 100X)

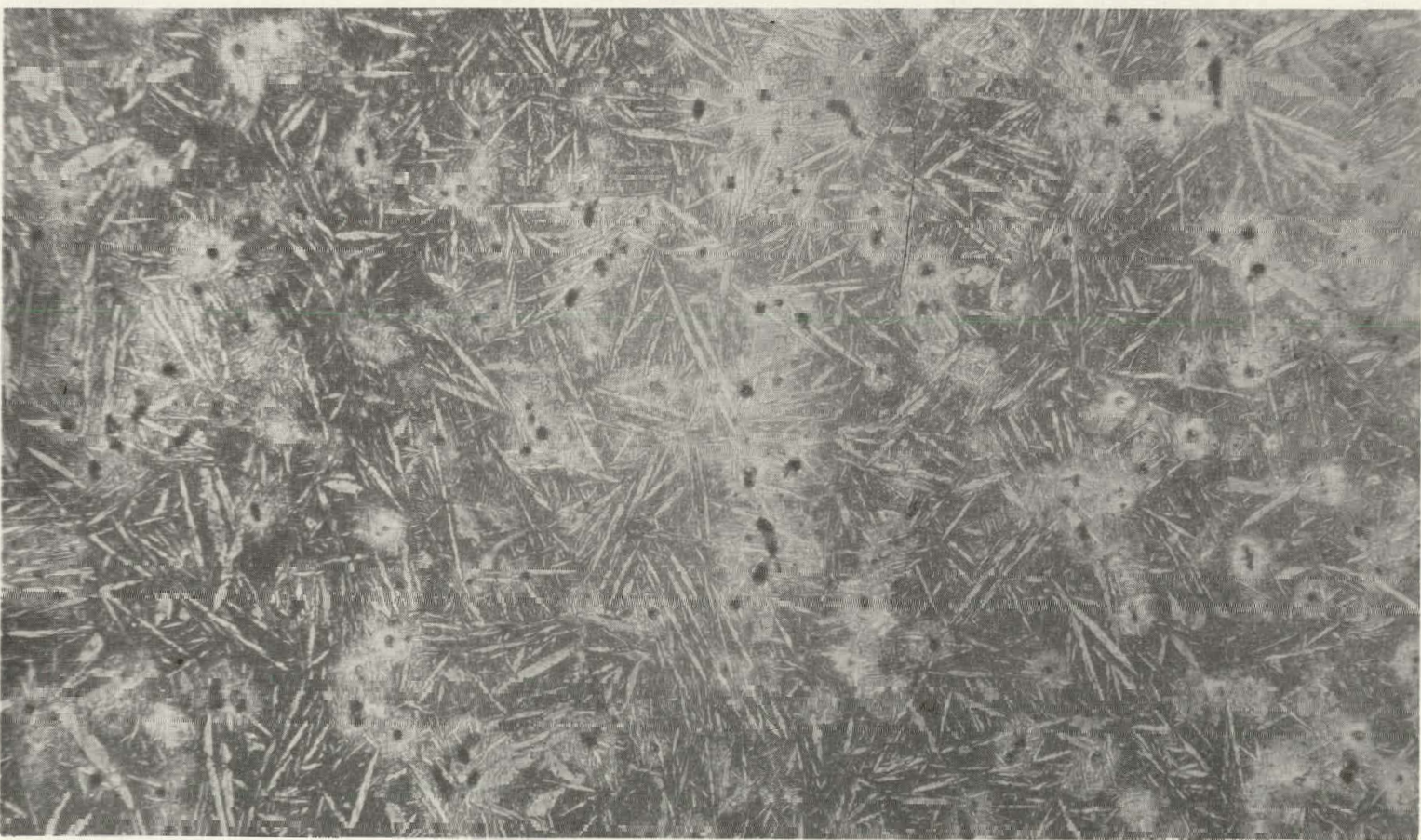

L125-2A

Figure 10. PHOTOMICROGRAPH OF URANIUM-2 WT \% ZIRCONIUM ALLOY THAT WAS GAMMA QUENCHED AND OVERAGED AT $400^{\circ}$ C FOR 24 HOURS. (Bright Field Illumination; 100X) 
Table 2

MODULI (SONIC) OF URANIUM-1 AND 2 WT \% ZIRCONIUM

ALLOYS IN THE AGED CONDITION

(Average of 2 Tests)

\begin{tabular}{lcc}
\hline & Uranium-1 wt \% Zirconium & Uranium-2 wt \% Zirconium \\
\hline Density $\left(\mathrm{g} / \mathrm{cm}^{3}\right)$ & 18.72 & 18.35 \\
Youngs Modulus $\left(\mathrm{MPa} \times 10^{4}\right)$ & 19.2 & 18.9 \\
Shear Modulus $\left(\mathrm{MPa} \times 10^{4}\right)$ & 7.5 & 7.6 \\
Poisson's Ratio & 0.28 & 0.24 \\
\hline
\end{tabular}

uranium. Hardening response of the $1 \mathrm{wt} \%$ alloy is small, but it is much higher with the $2 \mathrm{wt}$ $\%$ alloy. With both alloy levels, most of the hardening occurs on quenching, and both overage. in the $400^{\circ} \mathrm{C}$ treatment. The alloys respond to aging in a manner somewhat similar to the uranium-titanium alloys at comparable atomic-percent compositions. 


\section{REFERENCES}

(1) Chiswik, H. H., Dwight, A. E., Lloyd, L. T., Nevitt, M. V., and Zegler, S. T.; "Advances in the Physical Metallurgy of Uranium and Its Alloys", Proceedings of the 2nd International Conference, P/793, p 394 (1958).

(2) Johnson, J. R., Jr; Unpublished Work, Union Carbide Corporation-Nuclear Division, Oak Ridge Y-12 Plant, Oak Ridge, Tennessee.

(3) Hemperly, V. C.; Compilation of the Mechanical Properties of Dilute 15 Percent Maximum) Alloys of Uranium, Y-DA-3616; Union Carbide Corporation-Nuclear Division, Oak Ridge Y-12 Plant, Oak Ridge, Tennessee; September 22, 1970

(4) Ammons, A. D., "Precipitation Hardening in Uranium-Rich Uranium-Titanium Alloys", In Physical Metallurgy of Uranium Alloys, edited by J. J. Burke, D. A. Colling, A. E. Gorum, and J. Greenspan; Brookhill Publishing Company, Chestnut Hill, Massachusetts (1975). (Proceedings of the Physical Metallurgy of Uranium Alloys Conference, Vail, Colorado; February $12-14,1974$. 


\section{Distribution}

Energy Research and Development Administration - Oak Ridge

Hickman, H. D.

Leed, R. E.

Zachry, D. S., Jr

Lawrence Livermore Laboratory

Rizzo, H. F.

\section{Los Alamos Scientific Laboratory}

I lockett, J. [.

Kirby, R. S.

Sandstrom, D.

Taub, J. E.

Oak Ridge Gaseous Diffusion Plant

Stief, S. S.

Wilc.ox, W. J., Jr

\section{Oak Ridge National Laboratory}

Brinkman, C. R.

Martin, W. R.

McHargue, C. J.

Vandermeer, $R A$

\section{Oak Ridge Y-12 Plant}

Alvey, II. [.

Ammons, A. M.

Bcrnander, N. K.

Burditt, R. B.

Burkhart, L. E.

Dodson, W. I.

thert, $T, H$,

Ellingson, R. D.

Fraser, R. J.

Gritzner, V. B.

Hemperly, V. C. (5)

Jackson, V. C.

Jones, F. W.

Kahl, K. G.

Keith, A.

Kite, H. T.
Koger, J.W.

Ludwig, R. L.

Lundin, M. I.

Mills, J. M., Jr

Phillips, L. R.

Schreyer, J. M.

Smith, H. F., Jr

Smith, R.D.

Snyder, W. B., Jr

Stoner, $H$. H.

Tewes, W. E.

Tilson, F. V.

Yaggi, W. J./Googin, J. M.

$Y-12$ Central Files (5)

Y.12 Central Files (master copy)

$Y-12$ Central Files (route copy)

$Y-12$ Central Files (Y-12RC)

Zerby, C. D.

\section{Paducah Gaseous Diffusion Plant}

Levin, R. W.

Rockwell International - Rocky Flats

Jackson, R. J.

Jiannetti, $E$.

\section{Sandia - Albuquerque}

Màgnanı, iN. J.

McLaughlin, B.

Rohde, R. W.

Sallach, R. A.

Stephenson, L. L.

\section{Sandia - Livermore}

Adolphson, D. R.

Mute, M. W.

Weirick, L.

Zehr, S. W.

US Army Materials and Mechanical Research Center - Watertown

Levy, M.

Rizzitano, F.J. 